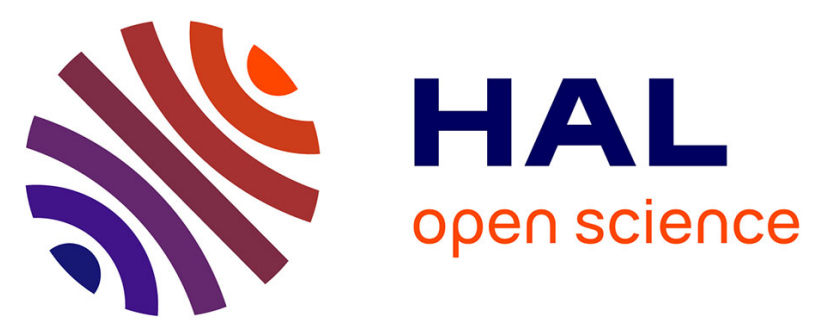

\title{
Mechanisms of metal-phosphates formation in the rhizosphere soils of pea and tomato: environmental and sanitary consequences
}

\author{
Annabelle Austruy, Muhammad Shahid, Tiantian Xiong, Maryse \\ Castrec-Rouelle, Virginie Payre, Nabeel Khan Niazi, Muhammad Sabir, \\ Camille Dumat
}

\section{To cite this version:}

Annabelle Austruy, Muhammad Shahid, Tiantian Xiong, Maryse Castrec-Rouelle, Virginie Payre, et al.. Mechanisms of metal-phosphates formation in the rhizosphere soils of pea and tomato: environmental and sanitary consequences. Journal of Soils and Sediments, 2014, 14 (4), pp.666-678. $10.1007 / \mathrm{s} 11368-014-0862-\mathrm{z}$. hal-01585025

\section{HAL Id: hal-01585025 https://hal.science/hal-01585025}

Submitted on 11 Sep 2017

HAL is a multi-disciplinary open access archive for the deposit and dissemination of scientific research documents, whether they are published or not. The documents may come from teaching and research institutions in France or abroad, or from public or private research centers.
L'archive ouverte pluridisciplinaire HAL, est destinée au dépôt et à la diffusion de documents scientifiques de niveau recherche, publiés ou non, émanant des établissements d'enseignement et de recherche français ou étrangers, des laboratoires publics ou privés. 


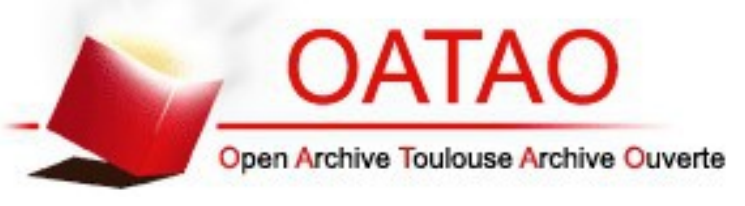

\section{Open Archive TOULOUSE Archive Ouverte (OATAO)}

OATAO is an open access repository that collects the work of Toulouse researchers and makes it freely available over the web where possible.

This is an author-deposited version published in : http://oatao.univ-toulouse.fr/ Eprints ID : 11345

To link to this article : DOI :10.1007/s11368-014-0862-z

URL : http://dx.doi.org/10.1007/s11368-014-0862-z

To cite this version : Austruy, Annabelle and Shahid, Muhammad and Xiong, Tiantian and Castrec-Rouelle, Maryse and Payre, Virginie and Niazi, Nabeel Khan and Sabir, Muhammad and Dumat, Camille Mechanisms of metal-phosphates formation in the rhizosphere soils of pea and tomato: environmental and sanitary consequences. (2014) Journal of Soils and Sediments, Vol. 14 ( $\left.\mathrm{n}^{\circ} 4\right)$. pp. 666-678. ISSN 1439-0108

Any correspondance concerning this service should be sent to the repository administrator: staff-oatao@,listes-diff.inp-toulouse.fr 


\title{
Mechanisms of metal-phosphates formation in the rhizosphere soils of pea and tomato: environmental and sanitary consequences
}

\author{
Annabelle Austruy • Muhammad Shahid • \\ Tiantian Xiong • Maryse Castrec • Virginie Payre • \\ Nabeel Khan Niazi • Muhammad Sabir • Camille Dumat
}

\begin{abstract}
Purpose At the global scale, soil contamination with persistent metals such as lead $(\mathrm{Pb})$, zinc $(\mathrm{Zn})$, and copper $(\mathrm{Cu})$ induces a serious threat of entering the human food chain. In the recent past, different natural and synthetic compounds have been used to immobilize metals in soil environments. However, the mechanisms involved in amendment-induced immobilization of metals in soil remained unclear. The objective of the present work was therefore to determine the mechanisms involved in metal-phosphates formation in the rhizospheric soils of pea and tomato currently cultivated in kitchen gardens.

Materials and methods Pea and tomato were cultivated on a soil polluted by past industrial activities with $\mathrm{Pb}$ and $\mathrm{Zn}$ under two kinds of phosphate (P) amendments: (1) solid hydroxyapatite and (2) $\mathrm{KH}_{2} \mathrm{PO}_{4}$. The nature and quantities of metal-P formed in the rhizospheric soils were studied by using the
\end{abstract}

A. Austruy $\cdot$ T. Xiong $\cdot$ V. Payre $\cdot$ C. Dumat $(\bowtie)$

INPT, UPS; EcoLab (Laboratoire Ecologie fonctionnelle et

Environnement); ENSAT, Université de Toulouse, Avenue de

1'Agrobiopole, 31326 Castanet-Tolosan, France

e-mail: camille.dumat@ensat.fr

A. Austruy

CNRS; EcoLab; ENSAT, 31326 Castanet-Tolosan, France

\section{Shahid $(\bowtie)$}

Department of Environmental Sciences, COMSATS Institute of Information Technology, Vehari 61100, Pakistan

e-mail: muhammadshahid@ciitvehari.edu.pk

M. Castrec

UMR 7618, Laboratoire BioMCo, Université Pierre et Marie Curie, PO box 120, 4 place Jussieu, 75251 Paris CEDEX 05, France

N. K. Niazi $\cdot$ M. Sabir

Institute of Soil and Environmental Sciences, University of

Agriculture Faisalabad, Faisalabad 38040, Pakistan selective chemical extractions and employing the combination of X-ray fluorescence micro-spectroscopy, scanning electron microscopy, and electron microprobe methods. Moreover, the influence of soil $\mathrm{pH}$ and organic acids excreted by plant roots on metal-P complexes formation was studied.

Results and discussion Our results demonstrated that $\mathrm{P}$ amendments have no effect on metal-P complex formation in the absence of plants. But, in the presence of plants, $\mathrm{P}$ amendments cause $\mathrm{Pb}$ and $\mathrm{Zn}$ immobilization by forming metal-P complexes. Higher amounts of metal-P were formed in the pea rhizosphere compared to the tomato rhizosphere and in the case of soluble P compared to the solid amendment. The increase in soil-metal contact time enhanced metal-P formation.

Conclusions The different forms of metal-P formed for the different plants under two kinds of $\mathrm{P}$ amendments indicate that several mechanisms are involved in metal immobilization. Metal-P complex formation in the contaminated soil depends on the type of $\mathrm{P}$ amendment added, duration of soil-plant contact, type of plant species, and excretion of organic acids by the plant roots in the rhizosphere.

Keywords Low molecular weight organic acids $\cdot$ Metal immobilization $\cdot$ Phosphates $\cdot$ Rhizosphere $\cdot$ Speciation

\section{Introduction}

The contamination of the human food chain with toxic metals such as $\mathrm{Pb}, \mathrm{Cd}, \mathrm{Cu}, \mathrm{Ni}, \mathrm{Zn}, \ldots$ has become inevitable owing to industrialization and the application of modern technologies (Radwan and Salama 2006; Austruy et al. 2013; Shahid et al. 2013a). The uptake of toxic metals by vegetables represents the main source of human exposure to environmental pollutants (Niazi et al. 2011a). As vegetables and fruits are the major components of human diet, their quality was studied in 
relation with soil (Uzu et al. 2009) or air pollution (Schreck et al. 2013). According to Sharma et al. (2008) or Foucault et al. (2013), the determination of the mechanisms involved in the soil-plant-human transfers of hazardous metals constitutes an important scientific goal. At the global scale, numerous soils are polluted with persistent metals with consequences on environmental and human health (Arshad et al. 2008; Shahid et al. 2012a; Pourrut et al. 2013). For example, in the USA, more than $60 \%$ of the contaminated sites from the National Priority List are polluted by metals and lead $(\mathrm{Pb})$ is reported to be the most common metal (present at $15 \%$ of the sites) (Suzuki et al. 2014). In Japan, according to the Ministry of Environment Government (2007), more than $40 \%$ of the contaminated sites are polluted by $\mathrm{Pb}$.

To contend with this problem, environmentally sustainable management of polluted sites is crucial. Among different remediation techniques, the in situ metal immobilization using chemical amendment together with plants has gained particular interest owing to its less disruptive nature and costeffectiveness (Lopareva-Pohu et al. 2011; Austruy 2012). The formation of metal-P complexes after the application of $\mathrm{P}$ amendments is considered as a major in situ stabilization approach for $\mathrm{Pb}$ and $\mathrm{Zn}$ polluted soils (Jiang et al. 2012; Mignardi et al. 2012). Certain Pb-P and $\mathrm{Zn}-\mathrm{P}$ minerals are highly stable with limited solubility in soils (Cao et al. 2009; Waterlot et al. 2011). Phosphorus-induced immobilization of metals in soil is recommended by the US Environmental Protection Agency as one of the best management practices for metal pollutants in soils (Chrysochoou et al. 2007).

Despite the useful effect of $\mathrm{P}$ amendments on $\mathrm{Pb}$ and $\mathrm{Zn}$ immobilization, the approach has some uncertainties as well, which need to be addressed before field scale application. One major drawback is the partial formation of stable metal-P complexes after $\mathrm{P}$ amendment. Although, the formation of metal-P complex after $\mathrm{P}$ addition to metal polluted soil is well established, the phenomenon is rather complex and generally incomplete. Several recent studies reported that more than $50 \%$ of $\mathrm{Pb}$ present in soil was not transformed into $\mathrm{Pb}-\mathrm{P}$ complex after P amendment (Hashimoto et al. 2009; Debela et al. 2013). The reduced formation of $\mathrm{Pb}-\mathrm{P}$ complexes is due to limited availability of free $\mathrm{P}$ and metals. In this way, the addition of $\mathrm{P}$ amendments at high rates may result in an excess of available $\mathrm{P}$, which can cause eutrophication of ground or surface waters (Park et al. 2011). This implies that P-induced metal immobilization in soil may endure economic and environmental consequences. The enhanced formation and thermodynamic stability of metal-P complexes particularly depends on physico-chemical soil characteristics such as mineral composition, $\mathrm{pH}$, organic contents, microbial activity, etc. (Lopareva-Pohu et al. 2011; Park et al. 2011; Mignardi et al. 2013). The increased solubilization and/or dissolution of metals in soils are generally related to changes in $\mathrm{pH}$ and/or complexing effects of organic acids (Shahid et al. 2012b, 2014a, b). Organic acids are also known to enhance metal solubilization and thus may favor the formation of metal-P complexes (Debela et al. 2010). Moreover, formation of metal-P complexes is also influenced by the presence of high amounts of $\mathrm{Fe}$ and $\mathrm{Mn}$ oxides or multi-metal $(\mathrm{Pb}, \mathrm{Zn}, \mathrm{Cd}, \ldots)$ contaminated soils.

In terms of transfers and ecotoxicity, the impact of metal(loid)s on terrestrial ecosystems is strongly influenced by their compartmentalization and speciation and on-site variability (in bulk soil as well as in rhizosphere) (Niazi et al. 2011b; Schreck et al. 2011; Leveque et al. 2013; Shahid et al. 2012c, 2013b). Changes in metal speciation can occur under the action of plants and application of organic or inorganic amendments (Mignardi et al. 2012; Shahid et al. 2014c). For example, $\mathrm{P}$ amendments may change metal speciation in soil and in turn, its bioavailability. A few studies concern the quantification of phosphate phases formed and the mechanisms involved. Therefore, a good understanding of the underlying mechanisms is required in order to predict, model, and optimize metal immobilization in treated polluted soils. The objectives of the present work were to: (1) locate $\mathrm{Pb}$ and $\mathrm{Zn}$ in the root system and in the rhizosphere of pea and tomato by X-ray fluorescence micro-spectroscopy ( $\mu$-XRF), (2) identify (chemical analysis) metal-P formed under the action of the plant and/or in the presence of $\mathrm{P}$ amendments (solid or soluble), by electron microprobe and scanning electron microscopy interfaced with an energy-dispersive spectrometer (SEMEDS), (3) quantify metal-P formed in the different samples by SEM-EDS and automatic statistical treatment, and (4) check the influence of low molecular weight organic acids released by plant roots and $\mathrm{pH}$ on $\mathrm{P}-$ metal complex formation.

\section{Materials and methods}

\subsection{Study area}

A highly contaminated top soil $(0-5 \mathrm{~cm})$ under poplar trees was sampled for micro-culture experiments in the laboratory (see the chapter later for details). The sampled soil under those trees has not been disturbed for the last 50 years and therefore represents the possible minimum total metal accumulation in soil during the last five decades. The site is located $500 \mathrm{~m} \mathrm{NE}$ from the former Metaleurop Nord smelter in Northern France. Metaleurop was one of the largest European $\mathrm{Pb}$ - and $\mathrm{Zn}$ smelter during 1884-2004. In 2002, the atmospheric releases recorded from this smelter were 1, 17, and 31 tons, respectively for $\mathrm{Cd}, \mathrm{Pb}$, and $\mathrm{Zn}$ (Fritsch et al. 2010). The atmospheric releases from the smelter has contaminated over tens of $\mathrm{km}^{2}$ of nearby areas (Douay et al. 2009; Shahid et al. 2013c). The highly contaminated loamy clayed top soils classified as pseudogley brown leached soils developed over quaternary clays $(0.6-1.5 \mathrm{~m})$ covering the Ostrincourt sand in which the 
water table is $1 \mathrm{~m}$ below ground level (Dumat et al. 2001). The physico-chemical properties of soils are: $\mathrm{pH}$ 6, OM $104 \mathrm{mg} \mathrm{kg}^{-1}$, and CEC $21.3 \mathrm{cmol}^{(+)} \mathrm{kg}^{-1}$. Soil concentrations of $\mathrm{Pb}, \mathrm{Cd}, \mathrm{Zn}$, and $\mathrm{Cu}$ are higher than the legal French limits except for $\mathrm{Cu}(100,300,2$, and $100 \mathrm{ppm}$, respectively for $\mathrm{Pb}$, $\mathrm{Zn}, \mathrm{Cd}$, and $\mathrm{Cu}$ ). In this top soil, $\mathrm{Pb}$ and $\mathrm{Zn}$ are mainly associated with $\mathrm{Fe}$ and $\mathrm{Mn}$ oxides and organic matters (Dumat et al. 2001). The concentrations of $\mathrm{Fe}, \mathrm{Mn}, \mathrm{Al}, \mathrm{Si}$, and $\mathrm{P}$, respectively are: $27,246 \mathrm{mg} \mathrm{kg}^{-1} \pm 2.8 \%, 498 \mathrm{mg} \mathrm{kg}^{-1}$ $\pm 3.1 \%, 41,900 \mathrm{mg} \mathrm{kg}^{-1} \pm 4 \%, 33,420 \mathrm{mg} \mathrm{kg}^{-1} \pm 3.2 \%$, and $330 \mathrm{mg} \mathrm{kg}^{-1} \pm 3.4 \%$ (Table 1 ).

\subsection{Culture experiments}

Seeds of pea (Pisum sativumpea L.) and tomato (Lycopersicon esculentum L.) were germinated in an aerated solution of $\mathrm{CaCl}_{2}(600 \mu \mathrm{M})+\mathrm{H}_{3} \mathrm{BO}_{3}(2 \mu \mathrm{M})$ after disinfection with $\mathrm{H}_{2} \mathrm{O}_{2}(6 \%)$. After 1 week, the uniform and healthy seedlings were transplanted to an aerated nutrient solution for 14 days of pre-culture. The composition of the nutrient solution was: $1 \mathrm{mM} \mathrm{Ca}\left(\mathrm{NO}_{3}\right)_{2}, 1 \mathrm{mM} \mathrm{KNO}_{3}, 1 \mathrm{mM} \mathrm{KCl}, 1 \mathrm{mM} \mathrm{MgSO}$, $0.5 \mathrm{mM} \mathrm{NaH}_{2} \mathrm{PO}_{4}, 6 \mu \mathrm{M}$ FeEDDHA $\left(\mathrm{C}_{18} \mathrm{H}_{20} \mathrm{O}_{6} \mathrm{~N}_{2}\right.$, ethylene diamine di (o-hydroxyphenylacetic) acid), $10 \mu \mathrm{M} \mathrm{H}_{3} \mathrm{BO}_{3}$, $2 \mu \mathrm{M} \mathrm{MnCl}_{2}, 1 \mu \mathrm{M} \mathrm{ZnCl}, 0.2 \mu \mathrm{M} \mathrm{CuCl}_{2}$, and $0.05 \mu \mathrm{M}$ $\left(\mathrm{NH}_{4}\right)_{6} \mathrm{Mo}_{7} \mathrm{O}_{24}$. The nutrient solution was renewed on every 4th day to keep its composition and $\mathrm{pH}$ constant.

Three-week-old pea and tomato plants were exposed for seven days to contaminated soil (sampled from Metaleurop Nord smelter) and mixed with the following two types of $\mathrm{P}$ amendments: (1) water-soluble $\mathrm{KH}_{2} \mathrm{PO}_{4}$ and (2) solid hydroxyapatite, $\mathrm{Ca}_{5}\left(\mathrm{PO}_{4}\right)_{3} \mathrm{OH}$. Culture experiments were performed using a biotest first described by Niebes et al. (1993) and then adapted by Chaignon and Hinsinger (2003). A small PVC cylinder was closed by a polyamide net inserted into a larger cylinder, itself closed by a finer polyamide mesh. A space of $3 \mathrm{~mm}$ was left between the net and the finer mesh, where the roots could develop as a mat. This biotest device presents two main advantages: (1) the roots are physically

Table 1 Total trace metal and mineral element concentrations in studied soil (milligrams per kilogram)

\begin{tabular}{ll}
\hline Trace metals & Soil concentrations \\
\hline $\mathrm{Cd}$ & $32 \pm 9$ \\
$\mathrm{Cu}$ & $83 \pm 6$ \\
$\mathrm{Mn}$ & $498 \pm 15$ \\
$\mathrm{~Pb}$ & $4,151 \pm 270$ \\
$\mathrm{Zn}$ & $2,036 \pm 58$ \\
$\mathrm{Fe}$ & $27,246 \pm 763$ \\
$\mathrm{Al}$ & $41,900 \pm 1,676$ \\
$\mathrm{Si}$ & $33,420 \pm 1,069$ \\
$\mathrm{P}$ & $330 \pm 11$ \\
\hline
\end{tabular}

separated from the soil which enables total recovery of the shoots, roots, and soil (2) the thickness of the soil layer used enables it to be considered as rhizospheric soil and provides enough rhizospheric material to evaluate root-induced changes in metal speciation.

The $\mathrm{P}$ amendments were added at $9,000 \mathrm{mg} \mathrm{P} \mathrm{kg}^{-1}$ of soil for $\mathrm{Ca}_{5}\left(\mathrm{PO}_{4}\right)_{3} \mathrm{OH}$ and $120 \mathrm{mg} \mathrm{P} \mathrm{kg}{ }^{-1}$ of soil for $\mathrm{KH}_{2} \mathrm{PO}_{4}$. Metal content analysis using inductively coupled plasma atomic emission spectrometry (ICP-AES) showed that both the $\mathrm{P}$ amendments did not contain detectable $\mathrm{Cd}, \mathrm{Pb}$, or $\mathrm{Zn}$. Five replicates for each experimental condition were performed under controlled laboratory conditions $\left(\mathrm{T}=26^{\circ} \mathrm{C}\right.$ and humidity $=80 \%$ ). After the soil-plant contact period (i.e., 7 days), plants and rhizospheric soils were carefully removed from the devices.

\subsection{Analysis of metals distribution within plant roots}

In order to investigate the distribution of accumulated $\mathrm{Pb}$ and $\mathrm{Zn}$ within plant tissues, X-ray fluorescence microspectroscopy ( $\mu$-XRF) analysis was performed on plant roots. During the analysis, the samples were fixed and kept frozen using a Peltier freezing system. Experiments were carried out using a microscope (XGT7000, Horiba Jobin Yvon) equipped with an X-ray guide tube producing a finely focused beam with a $10 \mathrm{~mm}$ or $100 \mathrm{~mm}$ spot size (Rh X-ray tube, $30 \mathrm{kV}$, $1 \mathrm{~mA}$ equipped with an EDX detector), as described by Lapied et al. (2011).

\subsection{Analysis of metal-P in rhizospheric soil of pea}

To identify the formation of metal-P in the rhizosphere, the soil samples obtained after culture of pea and tomato were analyzed using SEM-EDS. The chemical composition of metal-P observed by SEM-EDS was determined by electronic micro probe. We focused on the pea rhizosphere for this analysis because the phases detected for tomato were more difficult to analyze due to their small size (nanometers).

\subsection{Quantification of metal-P in rhizospheric soil of pea and tomato}

In order to quantify the metal-P phases, energy-dispersive $\mathrm{X}$ ray $(\mathrm{EDX})$ analysis was carried out on the rhizospheric soil of both the plants after $\mathrm{P}$ amendments. Counting a mineral carrier and $\mathrm{Pb}-\mathrm{P}$ phases was carried out using EDX which classifies the chemical composition of minerals according to criteria defined by Kotula et al. (2003). The software (PGT ${ }^{\circledR}$ Autochem Class) was used to quantify $\mathrm{Pb} / \mathrm{P}$ ratio for the classification of metal-P minerals. For $\mathrm{Pb}$, the phases are classified as follows: $\mathrm{Pb} / \mathrm{P}=1.5$ for pyromorphite, $0.9<\mathrm{Pb} / \mathrm{P}$ $<1.5$ for $\mathrm{Ca}$-pyromorphite, and $\mathrm{Pb} / \mathrm{P} \leq 0.9$ for $\mathrm{Pb}$-apatite (Eighmy et al. 1997). Two uncultivated control soils were also 
analyzed to identify the effect of plants and the effect of phosphate type. The approach has also been applied to $\mathrm{Zn}$ to classify different forms of $\mathrm{Zn}-\mathrm{P}$ as following: $\mathrm{Zn} / \mathrm{P}=1.5$ for $\left.\mathrm{Zn}_{5}\left(\mathrm{PO}_{4}\right)_{3} \mathrm{OH}\right) ; 0.9<\mathrm{Zn} / \mathrm{P}<1.5$ for $\mathrm{CaZn}_{3}\left(\mathrm{PO}_{4}\right)_{3} \mathrm{OH}$ et $\mathrm{Zn} / \mathrm{P} \leq$ 0.9 for $\mathrm{ZnCa}_{4}\left(\mathrm{PO}_{4}\right)_{3} \mathrm{OH}$.

2.6 Measurements of soil $\mathrm{pH}$ and low molecular weight organic acids (LMWOA)

The influence of soil $\mathrm{pH}$ and LMWOA excreted by plant roots was observed on the formation of metal-P complexes in rhizospheric soil of pea and tomato. Soil $\mathrm{pH}$ was determined before and after culture in 1:2.5 soil/water suspensions after $0.5 \mathrm{~h}$ with a combination $\mathrm{pH}$ electrode. Organic acids were identified and quantified by capillary electrophoresis for different experimental conditions (rhizospheric soil of pea and tomato for both types of $\mathrm{P}$ amendments). Electrophoresis (PACE MDQ, Beckman) was equipped with an UV detector filters ( $\mu=214 \mathrm{~nm}$ ) to detect the presence of the LMWOA in the rhizosphere. Selected conditions to analyze the organic acids were: (1) capillary untreated silica; $75 \mu \mathrm{m} \times 375 \mu \mathrm{m}$ (diameter internal/external) $70-80 \mathrm{~cm}$ (effective length/actual), $\mathrm{T}=17{ }^{\circ} \mathrm{C}$; (2) organic acid buffer used without dilution (Interchim $5 \mathrm{mMol} \mathrm{L}^{-1}$ o-potassium hydrogenophtalate (a) $\mathrm{HOOCC}_{6} \mathrm{H}_{4} \mathrm{COOK}, 0.5 \mathrm{mMol} \mathrm{L}$ of CTAB* N-hexadecyl-N, N, N trimethylammonium bromide (b) in water stored at $40{ }^{\circ} \mathrm{C}$ ); (3) rinse TAO 20 psi_3 min; (4) injection 0.5 psi_5 s; and (5) separation$15 \mathrm{kV} \_13 \mathrm{~min} \_2.7 \mu \mathrm{A}$.

\subsection{Statistical analysis}

We performed one-way analysis of variance (ANOVA) to evaluate any interaction effects between different treatments. Statistica Edition'98 (StatSoft Inc., Tulsa, OK, USA) was used for all statistical analysis. The results of chemical analysis correspond to the mean of five replicates. For each bioassay, mean values with different letters are significantly different $(p<0.05)$ as measured by LSD Fisher test.

\section{Results and discussion}

3.1 $\mathrm{Pb}$ and $\mathrm{Zn}$ phytoavailability and spatial distribution in the plants roots

Figure 1 shows the effect of $\mathrm{P}$ amendments on $\mathrm{Pb}$ and $\mathrm{Zn}$ uptake by pea and tomato plants. Addition of soluble $\mathrm{P}$ amendment significantly increased $\mathrm{Pb}$ contents in the roots of pea $(32 \%)$ and tomato $(10 \%)$ and $\mathrm{Zn}$ content $(14 \%)$ in the pea roots. In tomato roots, $\mathrm{Zn}$ contents were the opposite trend (decreased by $54 \%$ ). In case of solid P amendments, both the

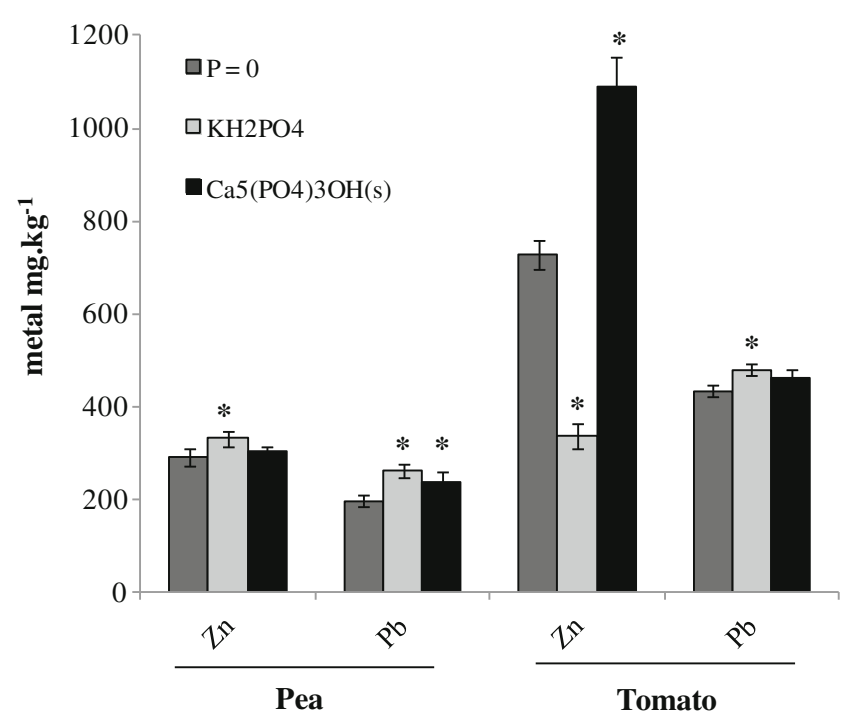

Fig. 1 Lead and zinc concentrations (milligrams per kilogram dry plant) in the roots of tomato and pea cultivated in soils with the various $\mathrm{P}$ conditions $\left(\mathrm{P}=0\right.$ or $\mathrm{P}$ as $\mathrm{KH}_{2} \mathrm{PO}_{4}$ or $\left.\mathrm{Ca}_{5}\left(\mathrm{PO}_{4}\right)_{3} \mathrm{OH}(\mathrm{s})\right)$. Data are means $\pm \mathrm{SD}$ of five replicates. Significant differences between treatments at $\mathrm{P}<$ 0.05 are indicated with an asterisk as measured by a LD fisher test

$\mathrm{Pb}$ and $\mathrm{Zn}$ levels increased in the roots of pea and tomato but the effect was significant only for $\mathrm{Pb}(19 \%)$ in pea and $\mathrm{Zn}$ (49 \%) in tomato. Generally, application of $\mathrm{P}$ amendments induces a decrease in metal uptake by plants due to formation of $\mathrm{Pb}-\mathrm{P}$ complexes. In our study, the increase in $\mathrm{Pb}$ and $\mathrm{Zn}$ uptake by pea and tomato in the presence of $P$ can be due to increased plant biomass (Huang et al. 2012; Shahid et al. 2013d).

The accumulation of both the metals was higher in tomato roots compared to pea roots. One hypothesis to explain that phenomenon is the preferential formation of metal-P in the rhizosphere of pea limiting the phytoabsorption of the metals (Shahid et al. 2013d). Several previous studies reported the different effects of the plant on biogeochemical behaviors (mobility and uptake) of metals, which are generally attributed to root exudation of organic acids of various type and at different levels (Shahid et al. 2012d). These organic acids are well known to affect metal mobility in soil and uptake by plant roots. However, the plant capacity to secrete organic acids with respect to type and amount varies under metal stress conditions; certain plants are capable to exudate relatively higher levels of organic acids and macromolecular to promote metal dissolution in soil (Jiang et al. 2012). Moreover, Zn was taken up in higher amount than $\mathrm{Pb}$ by both plants. Generally, $\mathrm{Pb}-\mathrm{P}$ is effectively less soluble and phytoavailable than $\mathrm{Zn}-\mathrm{P}$ and the affinity of phosphorus for $\mathrm{Pb}$ is greater compared to $\mathrm{Zn}$ (Panfili et al. 2005). The total metal analysis in the plant roots performed by $\mu$-XRF verified our results that the absorption of $\mathrm{Zn}$ was higher than $\mathrm{Pb}$ for both pea and tomato plants after 1 week of soil-plant contact with soluble $\mathrm{KH}_{2} \mathrm{PO}_{4}$ (Fig. 2). 

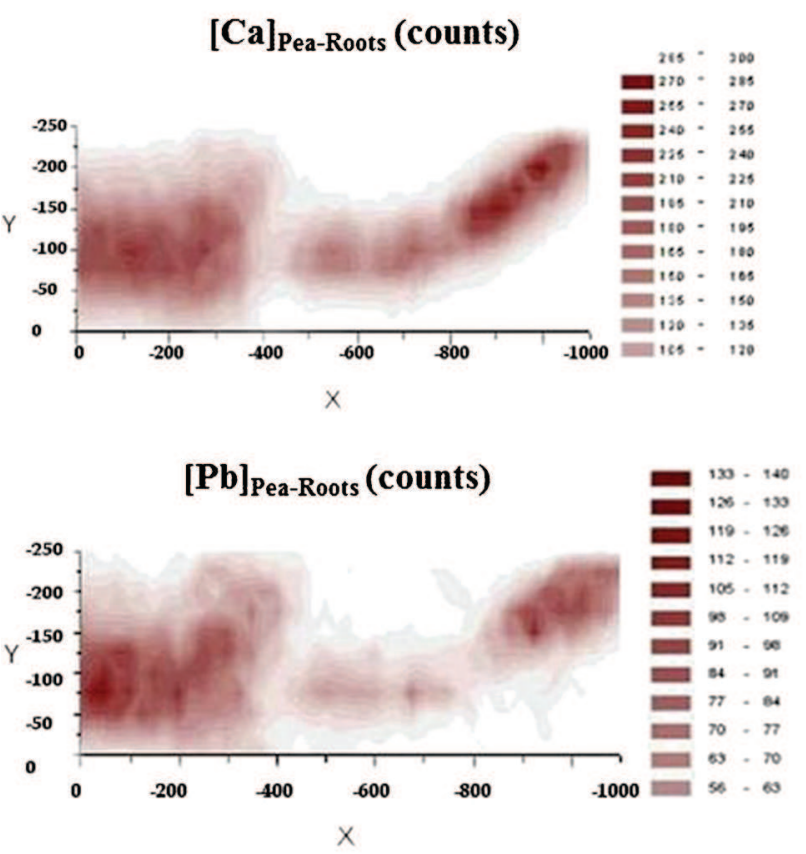

$[\mathbf{P b}]_{\text {Tomato-Roots }}$ (counts)

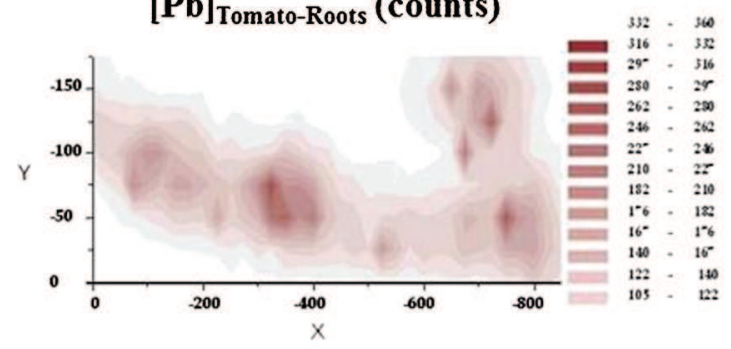

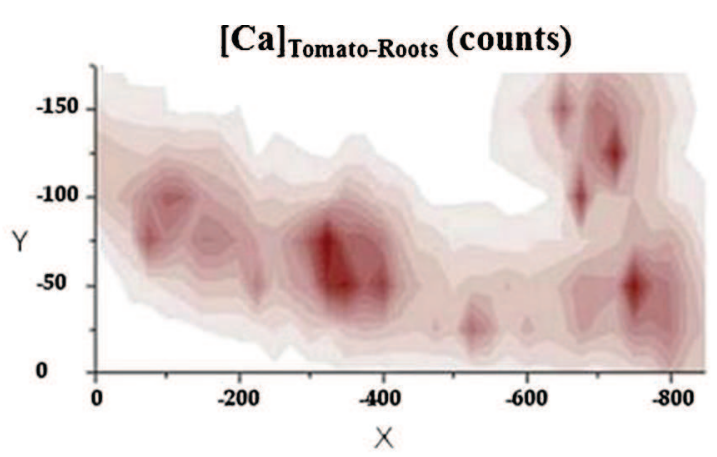
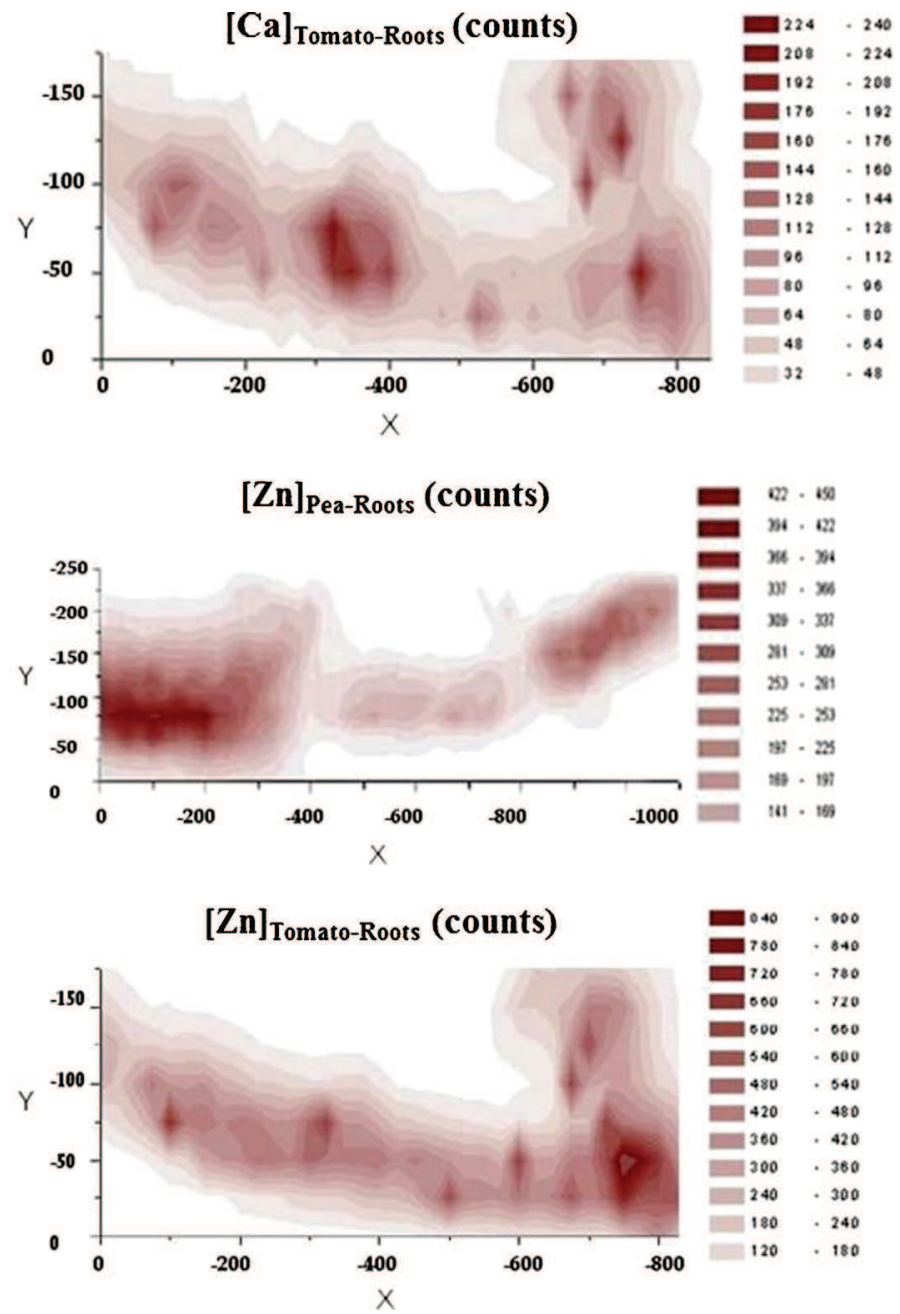

Fig. 2 Spatial distribution of $\mathrm{Pb}$ and $\mathrm{Zn}$ in the root systems of pea and tomato determined by $\mu \mathrm{FX}$ after plant cultures on the polluted soil amended with $\mathrm{KH}_{2} \mathrm{PO}_{4}$

\subsection{Observations, chemical analysis, and quantification of metal-P compounds}

Formation of metal-P in P-treated soils was further supported by SEM-EDS analysis (Fig. 3). Micrometer-sized minerals crystallize in large quantities in the pea rhizosphere were observed for soluble P. The electron microprobe analysis of minerals observed by SEM-EDS clarified their chemical composition as hydroxyl-pyromorphite $\left(\mathrm{Pb}_{5}\left(\mathrm{PO}_{4}\right)_{3}(\mathrm{OH})\right)$ (Fig. 3a). For solid $\mathrm{P}$ amendments, various $\mathrm{Pb}-\mathrm{Ca}-\mathrm{P}$ associations were observed by SEM-EDS (Fig. 3b) probably due to formation of $\mathrm{Pb}$-substituted $\mathrm{Ca}-\mathrm{P}$ mineral or $\mathrm{Pb}$ sorption on the Ca-P mineral (Cao et al. 2009). Using SEM-EDS technique, several previous studies also reported the formation of pyromorphite-like minerals in $\mathrm{Pb}$-contaminated soils in the presence of P amendments (Debela et al. 2013; Mignardi et al. 2013).

Figure 4 presents the data on the distribution of mineral metal-P phases obtained by microprobe analysis. These results are completed by the $\mathrm{P}$ amendments effects on quantification of metal-P complexes (pyromorphite, apatite, and other metal$\mathrm{P}$ complexes) in the presence and absence of plants (Table 2). The results for non-rhizospheric soil treated and untreated with soluble $\mathrm{P}$ indicate that the chemical composition of minerals is close to the $\mathrm{Fe}+\mathrm{Mn}$ pole (Fig. 4a, b). This finding is consistent with a common association of $\mathrm{Pb}$ with amorphous Fe and Mn oxides (Pourrut et al. 2011). Actually, application of $\mathrm{P}$ amendments to soils without plant culture has no effect on the formation of pyromorphite or apatite of $\mathrm{Pb}$ (Table 2). The effect of the $\mathrm{P}$ amendment alone on metal-P formation is, therefore, negligible. In the absence of plants, soluble $\mathrm{P}$ amendment altered $\mathrm{Pb}$ speciation by increasing $\mathrm{Ca}-$ pyromorphite (5\% against $3.1 \%$ for the untreated soil). The presence of solid $\mathrm{P}$ in non-rhizospheric soil results in the formation of $\mathrm{Pb}$-hydroxyapatite (close to $\mathrm{Ca}+\mathrm{P}$ pole). The results suggest mobilization of its initial $\mathrm{Pb}$-bearing phases (oxides of $\mathrm{Fe}, \mathrm{Mn}$ ) to a phosphate phase thus confirming the observations made by SEM imaging. These results were confirmed by the quantification of metal-P complexes (Table 2) which highlights that addition of solid 

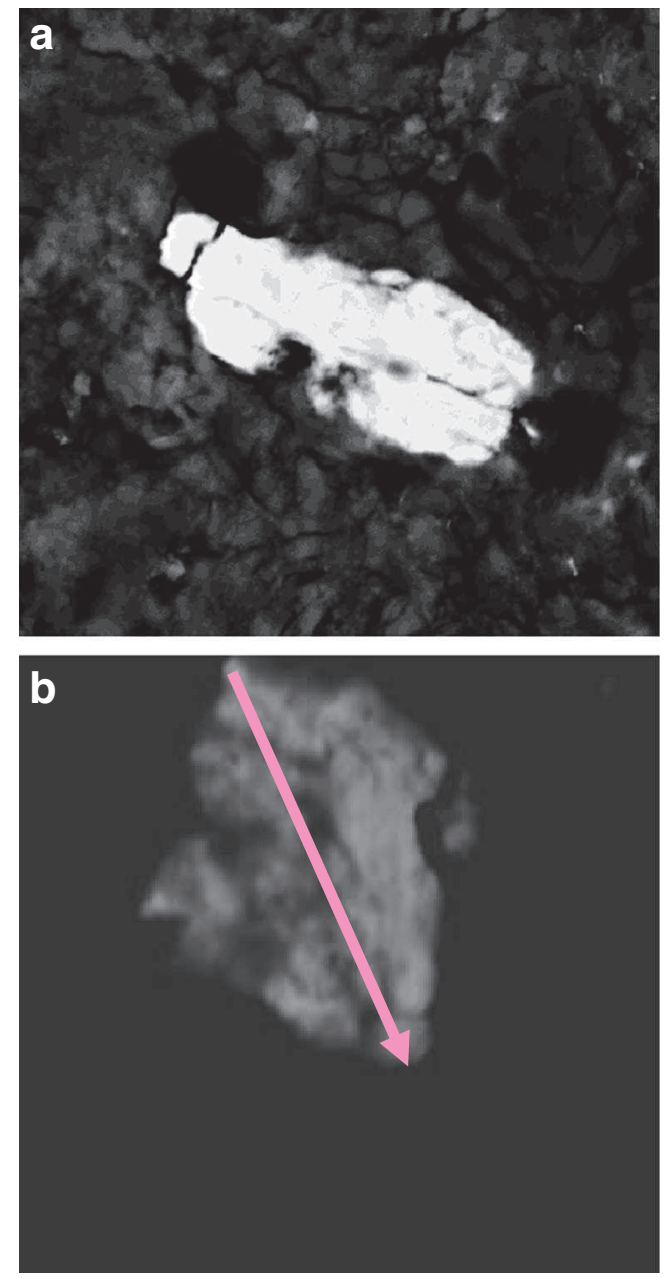

Fig. 3 Observation of Pb-phosphates in pea rhizosphere by SEM image and EDS analysis. a for soluble $\mathrm{KH}_{2} \mathrm{PO}_{4}$ amendment, $\mathrm{Pb}_{5}\left(\mathrm{PO}_{4}\right)_{3}(\mathrm{OH})_{2}$ (Hydroxypyromorphite) was observed. b for solid hydroxyapatite, the following Pb-Ca-P associations were observed: (1) $\mathrm{Ca}_{4.5} \mathrm{~Pb}_{0.5}\left(\mathrm{PO}_{4}\right)_{3} \mathrm{OH}$, (2) $\mathrm{Ca}_{4.0} \mathrm{~Pb}_{0.9}\left(\mathrm{PO}_{4}\right)_{3} \mathrm{OH}$, (3) $\mathrm{Ca}_{3.3} \mathrm{~Pb}_{1.7}\left(\mathrm{PO}_{4}\right)_{3} \mathrm{OH}$, and (4) $\mathrm{Ca}_{3.0} \mathrm{~Pb}_{2.0}\left(\mathrm{PO}_{4}\right)_{3} \mathrm{OH}$

$\mathrm{P}$ amendments to non-rhizospheric soil significantly enhanced $\mathrm{Pb}$-apatite formation.

The chemical composition of the mineral phases in the pea rhizosphere treated with soluble $\mathrm{P}$ is close to $\mathrm{Ca}+\mathrm{P}$ pole indicating a mixture of $\mathrm{Pb}$ and $\mathrm{Ca}+\mathrm{P}$. This suggests the formation of complex phosphates: $\mathrm{Ca}-\mathrm{P}, \mathrm{Pb}-\mathrm{P}$ and/or a mixed $\mathrm{Pb}-\mathrm{Ca}-\mathrm{P}$. Likewise, addition of solid $\mathrm{P}$ to pea rhizosphere resulted in chemical composition of minerals further close to the $\mathrm{Ca}+\mathrm{P}$ pole compared to non-rhizospheric soil, indicating the increased formation of $\mathrm{Pb}-\mathrm{P}$ phases. Indeed, the quantification of metal-P complexes (Table 2) shows P amendments changed $\mathrm{Pb}$ speciation in favor of the $\mathrm{Pb}$-apatite in rhizospheric soil ( $>90 \%$ against $0.4 \%$ for the untreated soil); the addition of $\mathrm{P}$ amendments also affected the formation and quantification of other $\mathrm{Pb}-\mathrm{P}$ complexes (decreased from $>90$ to $<1.1 \%$ ). The effect of solid $\mathrm{P}$ amendment was more intense compared to soluble $\mathrm{P}$ in the soils with or without plant
Fig. 4 Distribution of mineral phases in a ternary diagram: $(\mathrm{Mn}+\mathrm{Fe})$, $(\mathrm{Ca}+\mathrm{P})$, and $\mathrm{Pb}$ or $\mathrm{Zn}$, determined by microprobe analyzes. The center of the gray form locates point average composition. Rays indicate the standard deviation of the composition. a Case of soluble $\mathrm{P}$ addition for $\mathrm{Pb}, \mathbf{b}$ Case of solid $\mathrm{P}$ addition for $\mathrm{Pb}$, $\mathbf{c}$ Case of soluble $\mathrm{P}$ addition for $\mathrm{Zn}$, and $\mathbf{d}$ Case of solid $\mathrm{P}$ addition for $\mathrm{Zn}$

culture. Soluble $\mathrm{P}$ amendment enhanced the formation of $\mathrm{Pb}$-pyromorphite whereas solid $\mathrm{P}$ amendment favored $\mathrm{Ca}-$ pyromorphite formation in rhizospheric soil of both the plants.

In the case of $\mathrm{Zn}$, non-rhizospheric soil samples (untreated or treated with soluble $\mathrm{P}$ ) have a distribution similar to that observed for $\mathrm{Pb}$ phases (Fig. 4c, d). Both the amendments have no effect on $\mathrm{Zn}$ speciation in soils in the absence of plants (Table 2). Moreover, mineral phases in the pea rhizosphere are close to $\mathrm{Fe}+\mathrm{Mn}$ pole in the presence of soluble $\mathrm{P}$ compared to solid $\mathrm{P}$ amendment. This shows that pea plants have a low effect on the formation of $\mathrm{Zn}$-P complexes in the presence of soluble $\mathrm{P}$ amendment. Addition of solid $\mathrm{P}$ resulted in the composition close to the pole $(\mathrm{Ca}+\mathrm{P})$, indicating the mobilization of $\mathrm{Zn}$ primary phases to phosphates. Indeed, the $\mathrm{P}$ amendments allowed to significantly increase the amount of $\mathrm{Zn}$-apatite more abundant than other types of Zn-P complexes ( $>90 \%$ ). These results confirmed our above mentioned findings that plants favor the formation of metal-P complexes.

Our results indicate that the formation of $\mathrm{Pb}-\mathrm{P}$ depends on applied form of $\mathrm{P}$ amendments. The solid $\mathrm{P}$ amendment was more effective in forming $\mathrm{Pb}-\mathrm{P}$ complexes than soluble $\mathrm{P}$ amendment. The differences observed between soluble and solid $\mathrm{P}$ amendments towards metal-P formation were related to the availability of $\mathrm{P}$ and / or $\mathrm{Ca}$, if we assume a liquid phase for the formation of metal-P associations (Shahid et al. 2013d). This could be due to inability of solid P amendments to provide free phosphate because of its low dissolution / solubility in soil (Debela et al. 2013). In contrast, soluble P amendments provide high concentration of available $\mathrm{P}$ for the formation of $\mathrm{Pb}-\mathrm{P}$ minerals. However, it is not always wise to prefer soluble $\mathrm{P}$ amendments over solid $\mathrm{P}$ amendments because leaching of an excess of available $\mathrm{P}$ in the soil amended by soluble P may cause eutrophication of groundwater (Park et al. 2011; Tang and Yang 2012).

Moreover, the presence of plants favors the formation of $\mathrm{Pb}-\mathrm{P}$ complexes in soil after $\mathrm{P}$ amendments. The electron microprobe analysis of phases observed by SEM indicates that phosphates can be pure or mixed with $\mathrm{Ca}$ depending on the type of amendments. A number of researchers reported that formation of mineral phases containing $\mathrm{Pb}$ or $\mathrm{Zn}, \mathrm{Ca}$, and $\mathrm{P}$ involves different successive chemical reactions (Jiang et al. 2012; Mignardi et al. 2012). The results presented in the literature clearly support a mechanism of dissolution and precipitation for $\mathrm{Pb}-\mathrm{P}$ formation in soil after $\mathrm{P}$ application (Mignardi et al. 2013; Debela et al. 2013). Phosphate 

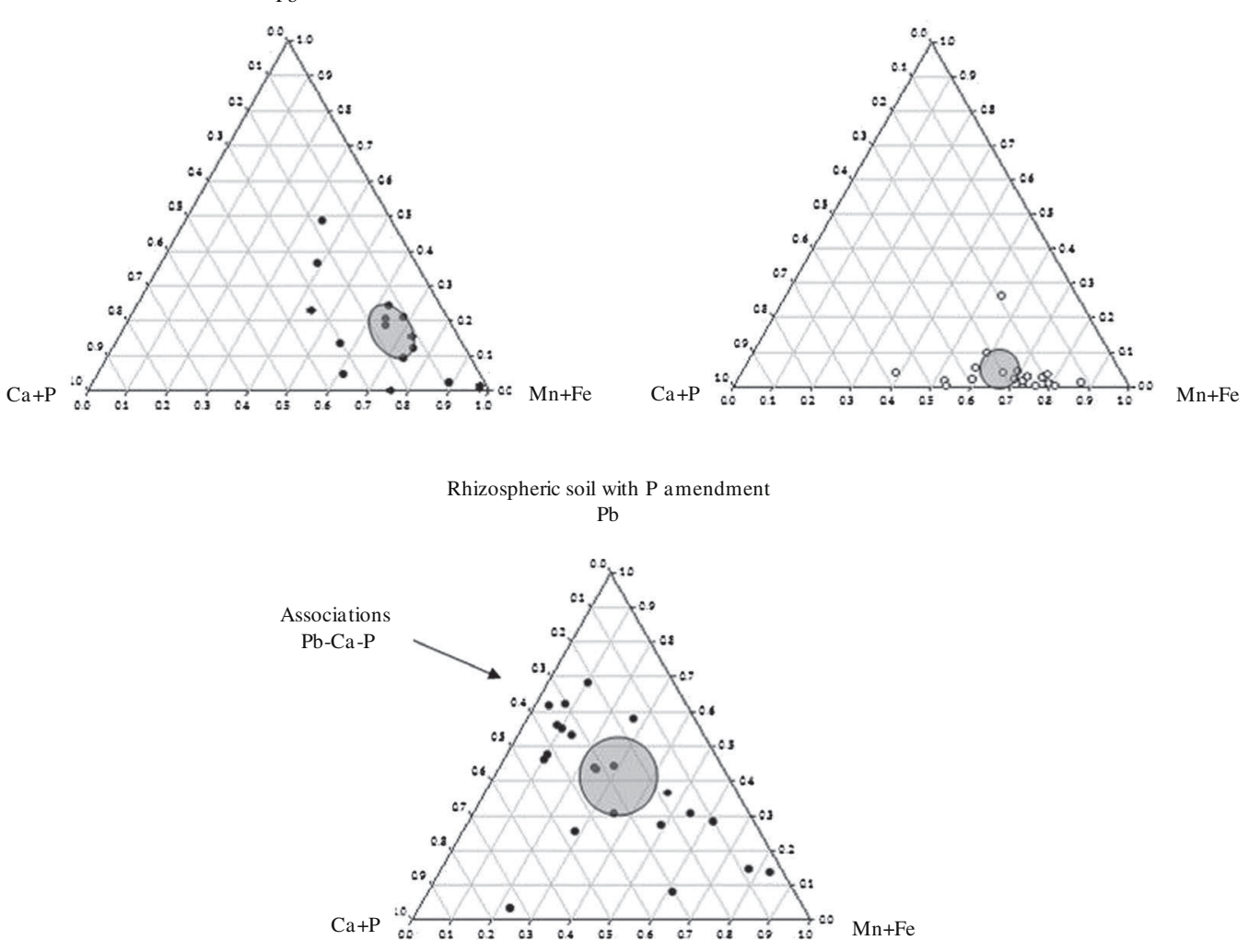

b
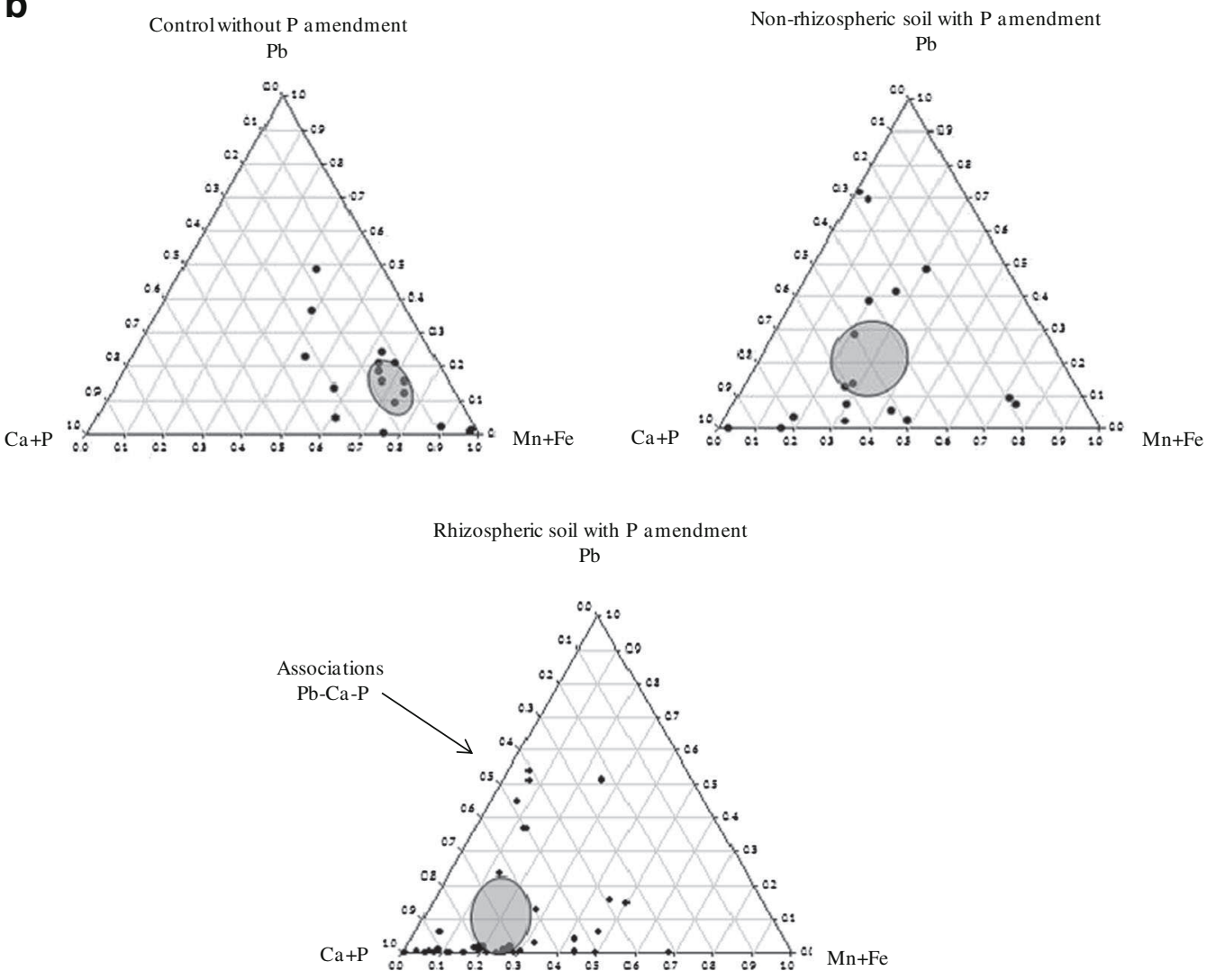
C

Control without $\mathrm{P}$ amendment

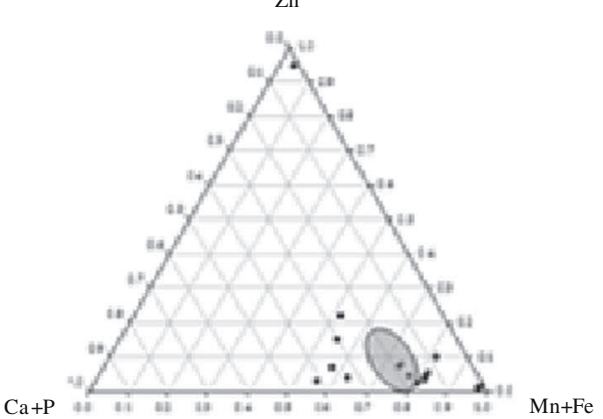

Non-rhizospheric soil with $\mathrm{P}$ amendment $\mathrm{Zn}$

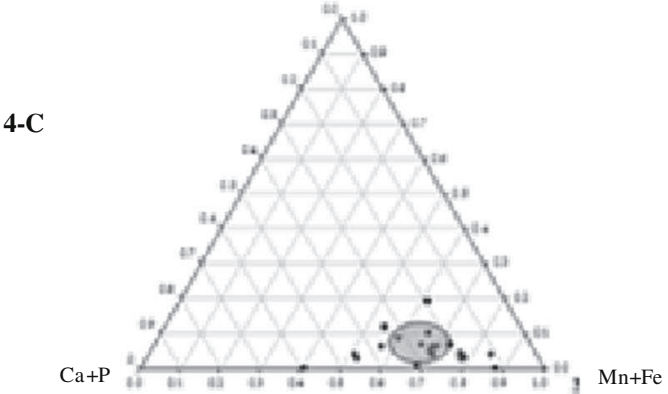

Rhizospheric soil with $\mathrm{P}$ amendment

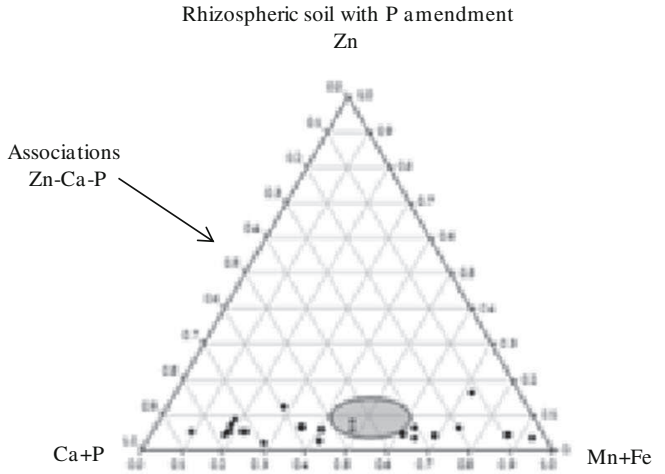

d

Control without $\mathrm{P}$ amendment

$$
\mathrm{Zn}
$$
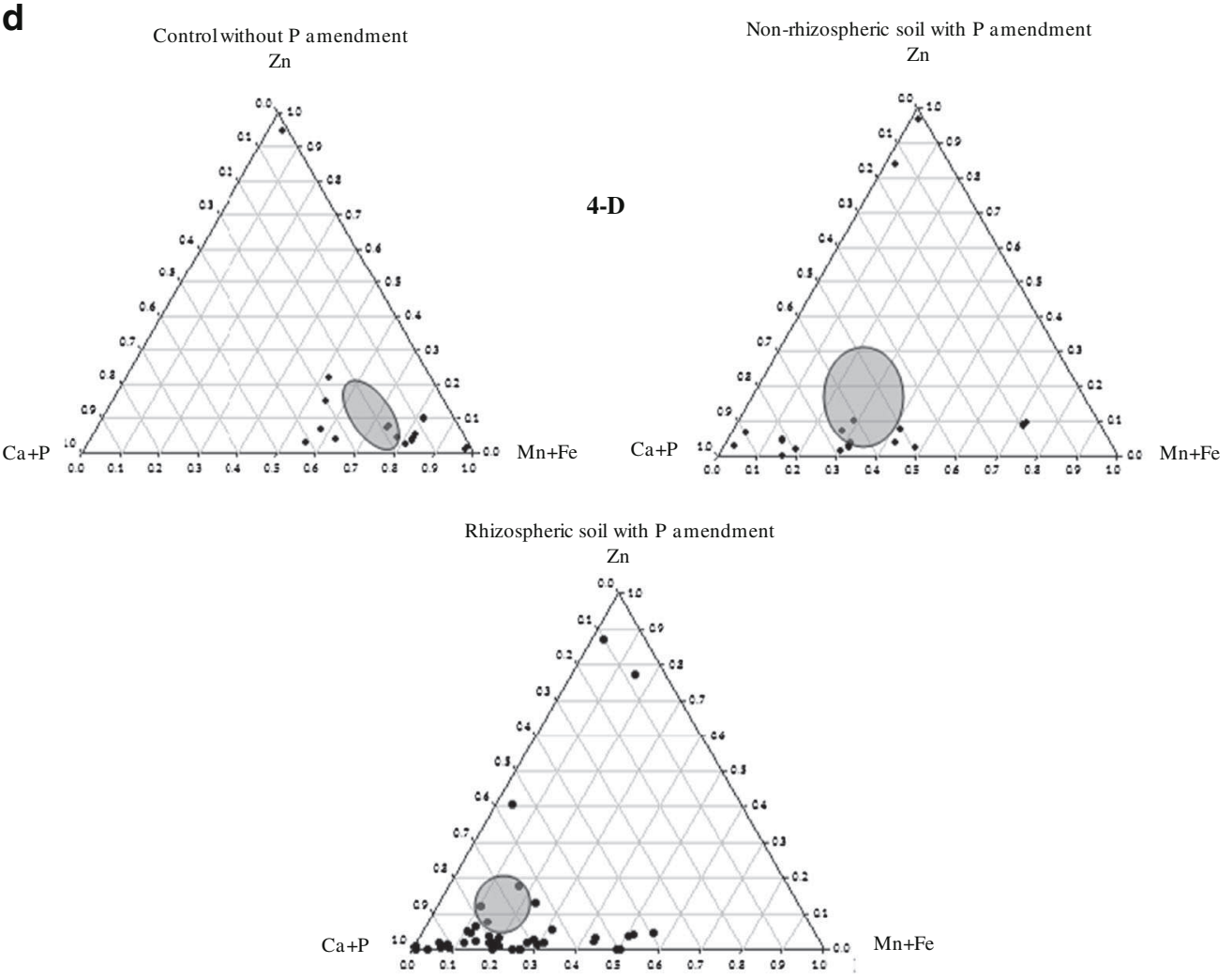

Fig. 4 (continued) 
Table 2 Percentage of $\mathrm{Pb}$-phosphates $\left[\left(\mathrm{Pb}_{5}\left(\mathrm{PO}_{4}\right)_{3} \mathrm{OH}\right.\right.$, Ca-pyromorphite and $\mathrm{Pb}$-apatite] and $\mathrm{Zn}$ phosphates $\left[\left(\mathrm{Zn}_{3}\left(\mathrm{PO}_{4}\right)_{2}\right.\right.$ or $\mathrm{Zn}_{5}\left(\mathrm{PO}_{4}\right)_{3} \mathrm{OH}$, $\mathrm{CaZn}_{3}\left(\mathrm{PO}_{4}\right)_{3}(\mathrm{OH})$ and $\left.\mathrm{ZnCa}_{4}\left(\mathrm{PO}_{4}\right)_{3}(\mathrm{OH})\right]$ determined by MEB-EDS analysis

\begin{tabular}{|c|c|c|c|c|c|c|c|c|c|}
\hline \multirow[t]{2}{*}{ Metal-phosphates } & \multicolumn{3}{|l|}{ Controls } & \multicolumn{2}{|c|}{ Tomato (1 week) } & \multicolumn{2}{|c|}{ Pea (1 week) } & \multicolumn{2}{|c|}{ Pea (3 weeks) } \\
\hline & $\begin{array}{l}\text { Untreated-P } \\
\text { control }\end{array}$ & $\begin{array}{l}\text { Soluble P } \\
\text { control }\end{array}$ & $\begin{array}{l}\text { Solid P } \\
\text { control }\end{array}$ & $\begin{array}{l}\text { Soluble P } \\
\text { tomato }\end{array}$ & $\begin{array}{l}\text { Solid P } \\
\text { tomato }\end{array}$ & $\begin{array}{l}\text { Soluble P } \\
\text { pea }\end{array}$ & $\begin{array}{l}\text { Solid P } \\
\text { pea }\end{array}$ & $\begin{array}{l}\text { Soluble P } \\
\text { pea }\end{array}$ & $\begin{array}{l}\text { Solid P } \\
\text { pea }\end{array}$ \\
\hline \multicolumn{10}{|l|}{$\mathrm{Pb}$} \\
\hline $\mathrm{Pb} 5(\mathrm{PO} 4) 3 \mathrm{OH})$ & 0.7 (a) & 0.9 (a) & 0.3 (a) & $2.9(\mathrm{ab})$ & 0.2 (a) & $7.2(b)$ & $3(a b)$ & $14(\mathrm{c})$ & 5 (a) \\
\hline Ca-pyromorphite & $3.1(\mathrm{ab})$ & 5 (b) & $4(a b)$ & 2 (a) & 6 (b) & 2 (a) & $4(a b)$ & $8(c)$ & 6 (b) \\
\hline $\mathrm{Pb}$-apatite & 0.4 (a) & 0.2 (a) & 6 (b) & $94(\mathrm{c})$ & 93 (c) & $90.8(\mathrm{c})$ & $92(\mathrm{c})$ & $78(\mathrm{c})$ & $89(\mathrm{c})$ \\
\hline Other $\mathrm{Pb}-\mathrm{P}$ & $95.8(d)$ & 93.9 (d) & 89.7 (d) & 1.1 (a) & 0.8 (a) & 0 & 1 (a) & 0 & 0 \\
\hline \multicolumn{10}{|l|}{$\mathrm{Zn}$} \\
\hline $\mathrm{Zn} 5(\mathrm{PO} 4) 3 \mathrm{OH}$ & 0 & 0 & 0 & 3 (a) & $1.3(\mathrm{a})$ & 7.4 (c) & 2 (a) & 18 (b) & 4 (a) \\
\hline $\mathrm{CaZn} 3(\mathrm{PO} 4) 3(\mathrm{OH})$ & 0.4 (a) & 0.3 (a) & 0.3 (a) & $2.3(\mathrm{a})$ & 6 (b) & 1.6 (a) & 3 (a) & 14 (b) & 4 (a) \\
\hline Zn-apatite & $9.2(b)$ & 4.7 (b) & $8.8(\mathrm{~b})$ & $95(\mathrm{c})$ & $93.2(\mathrm{c})$ & $92(\mathrm{c})$ & $95(\mathrm{c})$ & $68(\mathrm{c})$ & $92(\mathrm{c})$ \\
\hline Other Zn-P & $90.4(d)$ & 95 (d) & 90.9 (d) & 0 & 0 & 0 & 0 & 0 & 0 \\
\hline
\end{tabular}

One week and 3 weeks indicate exposure duration of P amendment; Rhizospheres (pea or tomato), after P amendment (soluble or solid), contact time 1 week, are compared with non-rhizospheric soil treated or untreated by $\mathrm{P}$ amendments. Unclassified phosphate forms: if $\mathrm{Pb} / \mathrm{P}>1.5$ and $\mathrm{Zn} / \mathrm{P}>1.5$. Moreover, for pea, data are also given after 3 weeks of soil-plant contact (Pea-3w) in addition to 1 week data. The different letters identify a significant difference at $p<0.05$

amendments also participate in the immobilization of $\mathrm{Zn}$ to form Zn-P (Raicevic et al. 2009). In particular, the fixation mechanism involves the formation of $\mathrm{Zn}-\mathrm{P}$ on the surface of the amendment grains, followed by the diffusion of $\mathrm{Zn}$ ions into the P structure. The co-precipitation of these metals to form polymetallic phosphate was also observed by Crannell et al. (2000).

\subsection{Effect of soil-plant contact time on metal-P formation}

The influence of soil-plant contact time for P amendments was only tested in the case of pea plant only. The percentages of $\mathrm{Zn}$ and $\mathrm{Pb}$-phosphates formed after 3 weeks of contact time were compared to the shorter period (1 week). Addition of soluble $\mathrm{P}$ amendment increased the formation of $\mathrm{Pb}$-pyromorphite (from 7 to $14 \%$ ) and Ca-pyromorphite (from 2 to $8 \%$ ) after 3 weeks compared to 1 week contact time. Similarly, solid P

Table 3 The $\mathrm{pH}\left(\mathrm{CaCl}_{2}\right)$ measured for different types (solid and soluble) and amounts $(0, \mathrm{P}, 3 \mathrm{P})$ intake of phosphate in the rhizosphere soils (peas and tomato) and controls $(\mathrm{P}=0$, non-rhizosphere soils

\begin{tabular}{lll}
\hline Amendments & Pea rhizosphere & Tomato rhizosphere \\
\hline $\mathrm{P}=0$ & $5.5 \pm 0.8(\mathrm{a})$ & $5.5 \pm 0.8(\mathrm{a})$ \\
P soluble & $5.4 \pm 0.9(\mathrm{a})$ & $5.4 \pm 0.7(\mathrm{a})$ \\
3P soluble & $5.1 \pm 0.9(\mathrm{a})$ & $5.7 \pm 0.7(\mathrm{a})$ \\
P solid & $5.5 \pm 0.6(\mathrm{a})$ & $5.1 \pm 0.8(\mathrm{a})$ \\
3P solid & $4.3 \pm 1.0(\mathrm{~b})$ & $4.7 \pm 0.6(\mathrm{ab})$
\end{tabular}

Different letters indicate that $\mathrm{pH}$ values are significantly different at $p$ $<0.05$ according to the LSD test amendment also increased $\mathrm{Pb}$-pyromorphite from 3 to $5 \%$ and Ca-pyromorphite from 4 to $6 \%$. Moreover, the fraction of $\mathrm{Pb}$-apatite decreased from 91 to $78 \%$ for soluble and from 92 to $89 \%$ for solid $\mathrm{P}$ amendment. For $\mathrm{Zn}$, the trend is similar but less effective to that observed for $\mathrm{Pb}$. These results indicate that a longer soil-plant contact time promotes the formation of stable $\mathrm{Pb}-\mathrm{P}$. Cao et al. (2009) also reported that water solubility of metals decreased with soil-metal contact time (aging) due to formation of stable and insoluble metal-P minerals. The key factors involved in the formation of stable metal-P minerals are the availability of free $\mathrm{P}$ and metals in soil solution in addition to soil physico-chemical characteristics (Debela et al. 2013). It is proposed that plants favor the formation of stable metal-P association by secreting organic acids. The high efficiency of soluble $\mathrm{P}$ amendment than solid $\mathrm{P}$ amendment to promote metal-P association with time could be probably due to availability of more soluble phosphate owing to its high dissolution (Shahid et al. 2013d).

Table 4 Percentage of $\mathrm{P}$ released from the apatite (after soluble $\mathrm{P}$ addition) in the supernatant under the effect of citric or tartaric acids (at concentrations observed in rhizospheres of pea and tomato)

\begin{tabular}{llllll}
\hline Sample & $\begin{array}{l}\text { Apatite+ } \\
\text { water }\end{array}$ & $\begin{array}{l}\text { Apatite+ } \\
\text { CA } \\
\text { Pea }\end{array}$ & $\begin{array}{l}\text { Apatite+ } \\
\text { CA } \\
\text { Tomato }\end{array}$ & $\begin{array}{l}\text { Apatite+ } \\
\text { TA } \\
\text { Pea }\end{array}$ & $\begin{array}{l}\text { Apatite+ } \\
\text { TA } \\
\text { Tomato }\end{array}$ \\
\hline $\begin{array}{c}\text { P release } \\
(\%)\end{array}$ & 0.2 & 12 & 6 & 32 & 25 \\
\hline
\end{tabular}

The results obtained for apatite mixed with deionized water (control) are also presented 
Table 5 Percentages of $\mathrm{P}, \mathrm{Pb}$, and $\mathrm{Zn}$ released from the polluted soil+ soluble $\mathrm{P}+$ citric acid in representative quantities of pea or tomato

\begin{tabular}{llll}
\hline Sample & Soil, soluble P & $\begin{array}{l}\text { Soil, soluble P } \\
\text { +CA-pea }\end{array}$ & $\begin{array}{l}\text { Soil, soluble P } \\
+ \text { CA-tomato }\end{array}$ \\
\hline P release (\%) & $0.1(\mathrm{a})$ & $15(\mathrm{c})$ & $12(\mathrm{~b})$ \\
Pb release (\%) & $0.1(\mathrm{a})$ & $34(\mathrm{c})$ & $26(\mathrm{~b})$ \\
Zn release (\%) & 0.05 (a) & $21(\mathrm{c})$ & $18(\mathrm{~b})$ \\
\hline
\end{tabular}

The results obtained for the polluted soil + soluble $\mathrm{P}$ and deionized water (control) are also presented. Different letters indicate that $\mathrm{pH}$ values are significantly different at $p<0.05$ according to the LSD test

\subsection{Effect of $\mathrm{P}$ amendments on soil $\mathrm{pH}$}

Table 3 presents the change in the rhizospheric $\mathrm{pH}$ of pea and tomato after the addition of $\mathrm{P}$ amendments at two levels $(9,000$ and $27,000 \mathrm{mg} \mathrm{P} \mathrm{kg}^{-1}$ of soil for $\mathrm{Ca}_{5}\left(\mathrm{PO}_{4}\right)_{3} \mathrm{OH}$ and 120 and $360 \mathrm{mg} \mathrm{P} \mathrm{kg}{ }^{-1}$ of soil for $\mathrm{KH}_{2} \mathrm{PO}_{4}$ ). The results show that neither the type nor the concentration of $\mathrm{P}$ amendments affects the $\mathrm{pH}$ significantly, except for the rhizospheric soil of pea after $2,700 \mathrm{mg} \mathrm{P} \mathrm{kg}^{-1}$ (3P) of solid amendments where $\mathrm{pH}$ was significantly decreased. The absence of significant differences in $\mathrm{pH}$ for pea and tomato invalidates the hypothesis of an effect of $\mathrm{pH}$ on the formation of metal-P. Valsami et al. (1998) showed that the dissolution of apatite
$\left([\mathrm{P}]=9,000 \mathrm{mg} \mathrm{kg}^{-1}\right)$ in the presence of $\mathrm{Pb}\left(450 \mathrm{mg} \mathrm{kg}^{-1}\right)$ first decreased soil $\mathrm{pH}$ from 5.5 to 4.4 and then increased to 5 . They explained this behavior by the formation of $\mathrm{Pb}$ phosphates hydroxypyromorphite. In our case, the $\mathrm{pH}$ did not change for solid and soluble $\mathrm{P}$ addition which may indicate the presence of a soil buffering effect. Recently, Jiang et al. (2012) reported that variation in soil solution $\mathrm{pH}$ from 2.0 to 5.0 has no effect on metal-P complex formation. Decrease in soil $\mathrm{pH}$ after the addition of solid phosphate at a concentration $27,000 \mathrm{mg} \mathrm{kg}^{-1}$ (3P), can be explained by the competition between $\mathrm{Pb}^{2+}, \mathrm{Ca}^{2+}$, and $\mathrm{H}^{+}$on the adsorption sites which results in the release of $\mathrm{H}^{+}$in the soil solution (Mavropoulos et al. 2002).

3.5 Role of the pea and tomato plants in the change of metal speciation

The amounts of low molecular weight organic acids excreted by the two plants species were measured for various experimental conditions. The pea plants excreted more citric and tartaric acids in comparison to tomatoes, 0.715 and $0.184 \mu \mathrm{M}$ of citric acid and 2.747 and $0.056 \mu \mathrm{M}$ of tartaric acid, respectively, for rhizospheric soils of pea and tomato. Other acids such as lactate, malonate, malate, and glycolate aconate were excreted in minor amounts. The effect of citric and tartaric acids, at quantities excreted by pea or tomato rhizospheres, on
Fig. 5 Schematic overview of the main soil-plant interactions observed

\section{$1-\mathrm{Zn}$ and $\mathrm{Pb}$ speciation in the rhizospheric soil is modified in presence of $P$ amendments}

Formation of metal-P

Mobilisation of $\mathrm{Zn}$ and $\mathrm{Pb}$ associated to oxides

$2-\mathrm{P}$ soluble input $\rightarrow$ most of metal-P compared to solid P input

3 - $\mathrm{P}$ solid input $\rightarrow$ most $\mathrm{Zn}$ and $\mathrm{Pb}$ mobilized from oxides

4- $\pi_{\text {of }} \mathrm{P}$ quantities $\boldsymbol{\lambda}_{\mathrm{Pb}}$ and $\mathrm{Zn}$ immobilisation

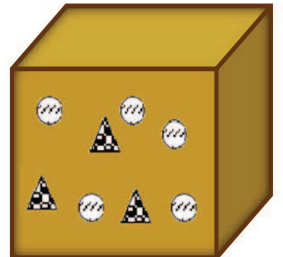

Non-rhizospheric soil $\mathrm{Pb}$ and $\mathrm{Zn}$ initially associated to $\mathrm{Fe}$ and $\mathrm{Mn}$ oxides and $\mathrm{OM}$

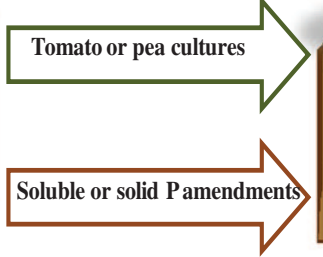

\section{Rhizospheric soil} Speciation changes $\mathrm{Pb}$ and $\mathrm{Zn}$ total quantities in the roots and soil

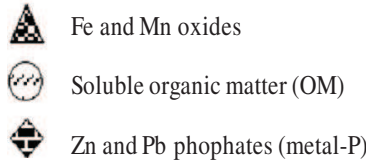


the release of $\mathrm{P}$ was tested in unpolluted control and metalcontaminated soil (Tables 4 and 5).

In unpolluted soil, citric acid significantly $(p<0.05)$ enhanced the amount of $\mathrm{P}$ released compared to control (12 and $6 \%$, respectively, for pea and tomato compared to $0.2 \%$ for control) (Table 4). The effect of tartaric acid on $\mathrm{P}$ release (32 and $25 \%$, respectively, for pea and tomato) was more significant compare to citric acid. In polluted soil, the release of $\mathrm{P}, \mathrm{Pb}$, and $\mathrm{Zn}$ increased from $0.1,0.1$, and $0.05 \%$ to respectively 15,34 , and $21 \%$ for pea and 12,26 , and $18 \%$ for tomato. The results suggest that citric acid caused the dissolution of apatite which results in the release of P. Organic acids are reported to enhance metal mobilization (Shahid et al. 2011; Niazi et al. 2011a) and mineral weathering by supplying both the protons and metal complexing anions (Fig. 5). Weng et al. (2002) reported release of P after mixing apatite and citric acid. The amounts of phosphorus released into solution by the apatite can then react with $\mathrm{Pb}$ and $\mathrm{Zn}$ to form metal-P complexes (Jiang et al. 2012). The proposed mechanism can be responsible for the enhanced formation of metal-P complexes by pea than tomato due to increased release of organic acids by pea (Fig. 5). There are at least two mechanisms by which phosphorus can be released under the influence of organic acids (Bolan et al. 1994). The first is the direct exchange of ligands on the mineral surface (e.g., on the surface of $\mathrm{Al}(\mathrm{OH})_{3}, \mathrm{Fe}(\mathrm{OH})_{3}$, the organic acid replaces $\mathrm{P}$ adsorbed on the surface). The second is the complexation of the metal cation in the solid phosphate phase implying $\mathrm{P}$ mobilization (e.g., $\mathrm{Ca}^{2+}$ in phosphate rock and precipitation of Ca-citrate or $\mathrm{Fe}^{3+}$ to $\left.\mathrm{Fe}(\mathrm{OH})_{3}\right)$. Generally, these two mechanisms occur simultaneously. Desorption and release of phosphorus however highly depends on soil type and concentration of organic acids (Bolan et al. 1994).

\section{Conclusions}

The coupling of chemical and spectroscopic methods allowed us to identify the metal-P formation based on their size and chemical composition in the rhizospheric soil. The maps produced by $\mu$-XRF, indicate that the soil-root transfer of $\mathrm{Zn}$ is larger than that of $\mathrm{Pb}$. The metal-P associations are mainly $\mathrm{Pb}$-Zn-apatite or apatite, Ca-pyromorphite or similar for $\mathrm{Zn}$ and phosphate pyromorphite or pure $\mathrm{Zn}$. The different forms of metal-P formed indicate that several mechanisms are involved in metal immobilization. Presence of plants significantly increases the formation of stable metal-P complexes by secreting the LMWOAs. The type and nature of metal-P complexes changed with the soil-metal contact time. We observed biggest metal-P complexes with increased soil-metal contact time. It is proposed that the contact time effect was also due to potential excretion of organic acids in the soil to promote the formation of stable and coarser metal-P solid phases.

With the development of gardening activities on strongly anthropogenic urban soils and $\mathrm{Pb}$ being often a major pollutant, the development of cultivation techniques that guarantee the quality of the harvest is an important research pursuit. The data obtained in this study provides avenues of research to reduce transfers of pollutants to plants commonly consumed in the gardens and reduces in consequence the human exposure to metals.

Acknowledgments This work has been supported by the National Research Agency under reference ANR-12-0011-VBDU and from ADEME, France.

\section{References}

Arshad M, Silvestre J, Pinelli E, Kallerhoff J, Kaemmerer M, Tarigo A, Shahid M, Guiresse M, Pradere P, Dumat C (2008) A field study of lead phytoextraction by various scented Pelargonium cultivars. Chemosphere 71:2187-2192

Austruy A (2012) Aspects physiologiques et biochimiques de la tolérance à l'arsenic chez les plantes supérieures dans un contexte de phytostabilisation d'une friche industrielle. Thèse de l'Université Blaise Pascal, Clermont Ferrand, $328 \mathrm{p}$

Austruy A, Wanat N, Moussard C, Vernay P, Joussein E, Ledoigt G, Hitmi A (2013) Physiological impacts of soil pollution and arsenic uptake in three plant species: Agrostis capillaris, Solanum nigrum and Vicia faba. Ecotoxicol Environ Saf 90:28-34

Bolan DNS, Naidu R, Mahimairaja S, Baskaran S (1994) Influence of low-molecular-weight organic acids on the solubilization of phosphates. Biol Fert Soils 18:311-319

Cao T, Wang M, An L, Yu Y, Lou Y, Guo S, Zuo B, Liu Y, Wu J, Cao Y et al (2009) Air quality for metals and sulfur in Shanghai, China, determined with moss bags. Environ Pollut 157:1270-1278

Chaignon V, Hinsinger P (2003) A biotest for evaluating copper bioavailability to plants in a contaminated soil. J Environ Qual 32:824-833

Chrysochoou M, Dermatas D, Grubb DG (2007) Phosphate application to firing range soils for $\mathrm{Pb}$ immobilization: The unclear role of phosphate. J Hazard Mater 144:1-14

Crannell BS, Eighmy TT, Krzanowski JE, Eusden JD Jr, Shaw EL, Francis CA (2000) Heavy metal stabilization in municipal solid waste combustion bottom ash using soluble phosphate. Waste Manag 20:135-148

Debela F, Arocena JM, Thring RW, Whitcombe T (2010) Organic acidinduced release of lead from pyromorphite and its relevance to reclamation of $\mathrm{Pb}$-contaminated soils. Chemosphere 80:450-456

Debela F, Arocena JM, Thring RW, Whitcombe T (2013) Organic acids inhibit the formation of pyromorphite and $\mathrm{Zn}$-phosphate in phosphorous amended $\mathrm{Pb}$ - and $\mathrm{Zn}$-contaminated soil. J Environ Manag 116:156-162

Douay F, Pruvot C, Waterlot C, Fritsch C, Fourrier H, Loriette A, Bidar G, Grand C, de Vaufleury A, Scheifler R (2009) Contamination of woody habitat soils around a former lead smelter in the North of France. Sci Total Environ 407:5564-5577

Dumat C, Chiquet A, Gooddy D, Aubry E, Morin G, Juillot F, Benedetti MF (2001) Metal ion geochemistry in smelter impacted soils and soil solutions. Bull Soc Geol Fr 172:539-548

Eighmy TT, Crannell BS, Butler LG, Cartledge FK, Emery EF, Oblas D, Krzanowski JE, EL Eusden S, Francis CA (1997) Heavy Metal 
Stabilization in Municipal Solid Waste Combustion Dry Scrubber Residue Using Soluble Phosphate. Environ Sci Technol 31:3330 3338

Foucault Y, Lévêque T, Xiong T, Schreck E, Austruy A, Shahid M, Dumat C (2013) Green manure plants for remediation of soils polluted by metals and metalloids: Ecotoxicity and human bioavailability assessment. Chemosphere 93:1430-1435

Fritsch C, Giraudoux P, Cœurdassier M, Douay F, Raoul F, Pruvot C, Waterlot C, de Vaufleury A, Scheifler R (2010) Spatial distribution of metals in smelter-impacted soils of woody habitats: influence of landscape and soil properties, and risk for wildlife. Chemosphere 81: 141-155

Hashimoto Y, Takaoka M, Oshita K, Tanida H (2009) Incomplete transformations of $\mathrm{Pb}$ to pyromorphite by phosphate-induced immobilization investigated by X-ray absorption fine structure (XAFS) spectroscopy. Chemosphere 76:616-622

Huang H, Li T, Gupta DK, He Z, Yang X-E, Ni B, Li M (2012) Heavy metal phytoextraction by Sedum alfredii is affected by continual clipping and phosphorus fertilization amendment. J Environ Sci 24:376-386

Jiang G, Liu Y, Huang L, Fu Q, Deng Y, Hu H (2012) Mechanism of lead immobilization by oxalic acid-activated phosphate rocks. J Environ Sci (China) 24:919-925

Kotula PG, Keenan MR, Michael JR (2003) Automated analysis of SEM $\mathrm{X}$-ray spectral images: a powerful new microanalysis tool. Microsc Microanal 9:1-17

Lapied E, Nahmani JY, Moudilou E, Chaurand P, Labille J, Rose J, Exbrayat J-M, Oughton DH, Joner EJ (2011) Ecotoxicological effects of an aged $\mathrm{TiO} 2$ nanocomposite measured as apoptosis in the anecic earthworm Lumbricus terrestris after exposure through water, food and soil. Environ Int 37:1105-1110

Leveque T, Capowiez Y, Schreck E, Mazzia C, Auffan M, Foucault Y, Austruy A, Dumat C (2013) Assessing ecotoxicity and uptake of metals and metalloids in relation to two different earthworm species (Eiseina hortensis and Lumbricus terrestris). Environ Pollut 179: 232-241

Lopareva-Pohu A, Pourrut B, Waterlot C, Garçon G, Bidar G, Pruvot C, Shirali P, Douay F (2011) Assessment of fly ash-aided phytostabilisation of highly contaminated soils after an 8-year field trial: part 1. Influence on soil parameters and metal extractability. Sci Total Environ 409:647-654

Mavropoulos E, Rossi AM, Costa AM, Perez CAC, Moreira JC, Saldanha M (2002) Studies on the mechanisms of lead immobilization by hydroxyapatite. Environ Sci Technol 36:1625-1629

Mignardi S, Corami A, Ferrini V (2012) Evaluation of the effectiveness of phosphate treatment for the remediation of mine waste soils contaminated with $\mathrm{Cd}, \mathrm{Cu}, \mathrm{Pb}$, and $\mathrm{Zn}$. Chemosphere 86:354-360

Mignardi S, Corami A, Ferrini V (2013) Immobilization of Co and Ni in Mining-Impacted Soils Using Phosphate Amendments. Water Air Soil Pollut 224:1-10

Ministry of Environment Government of Japan (2007) Current status of the Brownfields Issue in Japan Interim Report, pp. 1-26. http:// www.env.go.jp/en/water/soil/brownfields/interin-rep0703.pdf

Niazi NK, Bishop TFA, Singh B (2011a) Evaluation of spatial variability of soil arsenic adjacent to a disused cattle-dip site, using modelbased geostatistics. Environ Sci Technol 45:10463-10470

Niazi NK, Singh B, Shah P (2011b) Arsenic speciation and phytoavailability in contaminated soils using a sequential extraction procedure and XANES spectroscopy. Environ Sci Technol 45: $7135-7142$

Niebes J-F, Dufey JE, Jaillard B, Hinsinger P (1993) Release of nonexchangeable potassium from different size fractions of two highly K-fertilized soils in the rhizosphere of rape (Brassica napus cv Drakkar). Plant Soil 155-156:403-406

Panfili F, Manceau A, Sarret G, Spadini L, Kirpichtchikova T, Bert V, Laboudigue A, Marcus MA, Ahamdach N, Libert M-F (2005) The effect of phytostabilization on $\mathrm{Zn}$ speciation in a dredged contaminated sediment using scanning electron microscopy, X-ray fluorescence, EXAFS spectroscopy, and principal components analysis. Geochim Cosmochim Acta 69:2265-2284

Park JH, Bolan N, Megharaj M, Naidu R (2011) Isolation of phosphate solubilizing bacteria and their potential for lead immobilization in soil. J Hazard Mater 185:829-836

Pourrut B, Shahid M, Dumat C, Winterton P, Pinelli E (2011) Lead uptake, toxicity, and detoxification in plants. Rev Environ Contam Toxicol 213:113-136

Pourrut B, Shahid M, Douay F, Dumat C, Pinelli E (2013) Molecular mechanisms involved in lead uptake, toxicity and detoxification in higher plants. In: Gupta DK, Corpas FJ, Palma JM (eds) Heavy Metal Stress in Plants. Springer, Berlin, pp 121-147

Radwan MA, Salama AK (2006) Market basket survey for some heavy metals in Egyptian fruits and vegetables. Food Chem Toxicol 44: $1273-1278$

Raicevic S, Perovic V, Zouboulis AI (2009) Theoretical assessment of phosphate amendments for stabilization of $(\mathrm{Pb}+\mathrm{Zn})$ in polluted soil. Waste Manag 29:1779-1784

Schreck E, Foucault Y, Geret F, Pradere P, Dumat C (2011) Influence of soil ageing on bioavailability and ecotoxicity of lead carried by process waste metallic ultrafine particles. Chemosphere 85:15551562

Schreck E, Laplanche C, Le Guédard M, Bessoule J-J, Austruy A, Xiong T, Foucault Y, Dumat C (2013) Influence of fine process particles enriched with metals and metalloids on Lactuca sativa L. leaf fatty acid composition following air and/or soil-plant field exposure. Environ Pollut 179:242-249

Shahid M, Pinelli E, Pourrut B, Silvestre J, Dumat C (2011) Lead-induced genotoxicity to Vicia faba L. roots in relation with metal cell uptake and initial speciation. Ecotoxicol Environ Saf 74:78-84

Shahid M, Arshad M, Kaemmerer M, Pinelli E, Probst A, Baque D, Pradere P, Dumat C (2012a) Long-term field metal extraction by Pelargonium: phytoextraction efficiency in relation to plant maturity. Int J Phytorem 14:493-505

Shahid M, Dumat C, Aslam M, Pinelli E (2012b) Assessment of lead speciation by organic ligands using speciation models. Chem Spec Bioavailab 24:248-252

Shahid M, Dumat C, Silvestre J, Pinelli E (2012c) Effect of fulvic acids on lead-induced oxidative stress to metal sensitive Vicia faba $\mathrm{L}$. plant. Biol Fertil Soils 48:689-697

Shahid M, Pinelli E, Dumat C (2012d) Review of Pb availability and toxicity to plants in relation with metal speciation; role of synthetic and natural organic ligands. J Hazard Mater 219-220:1-12

Shahid M, Ferrand E, Schreck E, Dumat C (2013a) Behavior and impact of zirconium in the soil-plant system: plant uptake and phytotoxicity. Rev Environ Contam Toxicol 221:107-127

Shahid M, Dumat C, Pourrut B, Silvestre J, Laplanche C, Pinelli E (2013b) Influence of EDTA and citric acid on lead-induced oxidative stress to Vicia faba roots. J Soils Sediments. doi:10.1007/ s11368-013-0724-0

Shahid M, Xiong T, Castrec-Rouelle M, Leveque T, Dumat C (2013c) Water extraction kinetics of metals, arsenic and dissolved organic carbon from industrial contaminated poplar leaves. J Environ Sci 25: 2451-2459

Shahid M, Xiong T, Masood N, Leveque T, Quenea K, Austruy A, Foucault Y, Dumat C (2013d) Influence of plant species and phosphorus amendments on metal speciation and bioavailability in a smelter impacted soil: a case study of food-chain contamination. J Soils Sediments. doi: 10.1007/s11368-013-0745-8

Shahid M, Dumat C, Pourrut B, Sabir M, Pinelli E (2014a) Assessing the effect of metal speciation on lead toxicity to Vicia faba pigment contents. J Geochem Explor. doi:10.1016/j.gexplo.2014.01.003

Shahid M, Austruy A, Echevarria G, Arshad M, Sanaullah M, Aslam M, Nadeem M, Nasim W, Dumat C (2014b) EDTA-enhanced 
phytoremediation of heavy metals: a review. Soil Sediment Contam 23:389-416

Shahid M, Pinelli E, Pourrut B, Dumat C (2014c) Effect of organic ligands on lead-induced oxidative damage and antioxidant defence in the leaves of Vicia faba plants. J Geochem Explor. doi:10.1016/j. gexplo.2014.01.008

Sharma RK, Agrawal M, Marshall FM (2008) Heavy metal (Cu, Zn, Cd and $\mathrm{Pb}$ ) contamination of vegetables in urban India: A case study in Varanasi. Environ Pollut 154:254-263

Suzuki T, Niinae M, Koga T, Akita T, Ohta M, Choso T (2014) EDDSenhanced electrokinetic remediation of heavy metal-contaminated clay soils under neutral pH conditions. Coll Surf A: Physicochem Eng Aspects 440:145-150

Tang X, Yang J (2012) Long-term stability and risk assessment of lead in mill waste treated by soluble phosphate. Sci Total Environ 438:299 303
Uzu G, Sobanska S, Aliouane Y, Pradere P, Dumat C (2009) Study of lead phytoavailability for atmospheric industrial micronic and submicronic particles in relation with lead speciation. Environ Pollut 157:1178-1185

Valsami-Jones E, Ragnarsdottir KV, Putnis A, Bosbach D, Kemp AJ, Cressey G (1998) The dissolution of apatite in the presence of aqueous metal cations at $\mathrm{pH} 2-7$. Chem Geol 151:215-233

Waterlot C, Pruvot C, Ciesielski H, Douay F (2011) Effects of a phosphorus amendment and the $\mathrm{pH}$ of water used for watering on the mobility and phytoavailability of $\mathrm{Cd}, \mathrm{Pb}$ and $\mathrm{Zn}$ in highly contaminated kitchen garden soils. Ecol Eng 37:10811093

Weng W, Han G, Du P, Shen G (2002) The effect of citric acid addition on the formation of sol-gel derived hydroxyapatite. Mater Chem Phys 74:92-97 